\title{
Phylogeny of Legionellaceae Based on Small-Subunit Ribosomal DNA Sequences and Proposal of Legionella lytica comb. nov. for Legionella-Like Amoebal Pathogens
}

\author{
J. V. HOOKEY, ${ }^{1 *}$ N. A. SAUNDERS, ${ }^{1}$ N. K. FRY, ${ }^{2}$ R. J. BIRTLES, ${ }^{2}$ AND T. G. HARRISON ${ }^{2}$ \\ Molecular Biology Unit, Virus Reference Division, ${ }^{1}$ and Legionella Reference Unit, Respiratory and \\ Systematic Infection Laboratory, ${ }^{2}$ Central Public Health Laboratory, Colindale, \\ London NW9 5HT, United Kingdom
}

\begin{abstract}
The 16S rRNA-encoding gene sequences from strains of the family Legionellaceae, Sarcobium lyticum, and Coxiella burnetii were determined. Phylogenetic relationships revealed that all Legionella spp. were members of a coherent monophyletic family. The blue-white autofluorescent species formed a defined cluster bounded by Legionella bozemanii and Legionella tucsonensis. The strains of Legionella pneumophila subsp. pneumophila and Legionella pneumophila subsp. fraseri shared $99.2 \%$ sequence identity. A legionella-like amoebal pathogen (LLAP-3) showed 99.4\% sequence identity to the obligate intracellular bacterial parasite Sarcobium lyticum. A proposal is made for the transfer of Sarcobium lyticum from the genus Sarcobium to the genus Legionella as Legionella lytica comb. nov. On the basis of serology and phenetic and phylogenetic comparisons, the taxa Legionella erythra and Legionella rubrilucens may be regarded as subspecies.
\end{abstract}

The family Legionellaceae was initially proposed for a single genus (Legionella) and species (Legionella pneumophila) (10). Currently, there are 39 validly described species that have been isolated from either clinical or environmental sources or both (28). All species so far described are gram-negative rods, $0.3 \times$ $10^{-6}$ to $0.9 \times 10^{-6} \mathrm{~m}$ in width and $2 \times 10^{-6}$ to $20 \times 10^{-6} \mathrm{~m}$ or more in length, and polar flagella may be present (40). The legionellae all shared additional phenotypic characters that included absence of growth on blood agar, nitrate not being reduced, negative reaction for urease, a nonfermentative metabolism, a requirement for L-cysteine and iron salts for primary isolation on solid media, respiratory ubiquinones with 10 or more isoprene units, and a predominance of branched-chain cellular fatty acids $(5,6,34,52)$. The moles percent guanineplus-cytosine content $(\mathrm{mol} \% \mathrm{G}+\mathrm{C}$ ) ranges from 36.3 (Legionella cincinnatiensis [49]) to 52.0 for the type strains of Legionella geestiana (16) and Legionella rubrilucens (9).

Though bacterial species were defined on the basis of DNADNA hybridization data, the interpretation of low DNA hybridization values for some members of the genus Legionella resulted in a proposal to divide the family Legionellaceae into three genera: Legionella sensu stricto, Tatlockia, and Fluoribacter $(12,26)$.

In the current study, comparative $16 \mathrm{~S}$ rRNA-encoding gene (rDNA) sequencing analysis was employed to further delineate and refine the phylogeny of the Legionellaceae.

\section{MATERIALS AND METHODS}

Bacterial strains, culture conditions, and DNA preparation. Strains of Legionella (Table 1) were cultured on BCYE agar $(20)$ at $35^{\circ} \mathrm{C}$ in a humid chamber for up to 7 days. Chromosomal DNA was extracted after lysis with guanidium isothiocyanate reagent (42).

PCR amplification, purification, and automated PCR-directed cycle sequencing of 16S rDNA. Amplification was carried out as previously described (32), and the ca. 1,450 -bp product was purified according to the method of Zhen and

* Corresponding author. Mailing address: Molecular Biology Unit, Virus Reference Division, Central Public Health Laboratory, Colindale, London NW9 5HT, United Kingdom. Phone: 441812004400. Fax: 44181200 1569. Electronic mail address: jhookey@hgmp.mrc.ac .uk.
Swank (55). PCR products were sequenced directly with the Taq DyeDeoxy Terminator kit (Applied BioSystems) according to the manufacturer's protocol. The primers used were $\mathrm{pA}$ ( 8 to 20 ), $\mathrm{pC}$ ( $=\mathrm{pEM}, 341$ to 361 ), $\mathrm{pD}$ (518 to 536 ) and $\mathrm{pD}^{-}$(536 to 518$), \mathrm{pH}^{-}(1542$ to $1522[35,36]), \mathrm{pE} 4(1113$ to $1130[32])$, and 16 S1425r (19). The sequence reaction mixtures were electrophoresed with the Applied BioSystems 373A DNA sequencer.

Data analysis. Sequences were aligned against highly conserved regions by the Multalin alignment computer program (15). Regions of extreme hypervariability or ambiguity were removed from the alignment. Phylogenetic analyses were carried out on 46 strains for 1,345 nucleotides with the PHYLIP 3.52c Phylogenetic Inference Package (J. Felsenstein, University of Washington) supported on a SunOS 5.4 workstation at the Human Genome Mapping Program Resource Centre (Cambridge, United Kingdom). The reliability of three nodes was assessed by analyzing multiple data sets $(\times 100)$. Unrooted consensus trees were calculated from both parsimony (DNAPARS) and distance methods. Pairwise distances between all sequences were inferred from the Jukes and Cantor (33) one-parameter model (all substitutions are assumed to be equally likely) and under the maximum-likelihood (DNAML) criteria, whereby each branch of the phylogenetic tree was tested for statistical significance. Trees were constructed by neighbor joining (NEIGHBOR [41]) and by using the algorithm of Fitch and Margoliash (FITCH [21]). A majority-rule consensus tree was computed from trees derived from multiple data sets $(\times 100)$ by the CONSENSE program.

Nucleotide sequence accession numbers. The accession numbers of the Legionella nucleotide sequences obtained in this study by automated PCR cycling were as follows: Legionella adelaidensis, Z49716; Legionella anisa, Z32635; Legionella birminghamensis, Z49717; Legionella bozemanii, Z49718 and Z49719; Legionella brunensis, Z32636; Legionella cherrii, Z49720; L. cincinnatiensis, Z49721; Legionella dumoffii, Z32637; Legionella faiffieldensis, Z49722; Legionella feeleii, Z49740; Legionella gormanii, Z32639; L. geestiana, Z49723; Legionella gratiana, Z49725; Legionella israelensis, Z32640; Legionella jamestowniensis, Z49726; Legionella jordanis, Z32667; Legionella lansingensis, Z49727; Legionella londiniensis, Z49728; Legionella macheachernii, Z32641; Legionella moravica, Z49729; Legionella nautarum, Z49730; Legionella oakridgensis, Z32643; Legionella parisiensis, Z49731; Legionella quateirensis, Z49732; Legionella quintivanii, Z49733; L. rubrilucens, Z32643; Legionella sainthelensi, Z49734; Legionella santicnucis, Z49735; Legionella shakespearei, Z49736; Legionella steigerwaltii, Z49737; Legionella tucsonensis, Z32644; Legionella wadsworthii, Z49738; Legionella worsliensis, Z49739; and the isolate "Glasgow" 86/35785, Z49724. Sequences used for comparison in this study and those obtained by the reverse transcriptase method were as follows: L. bozemanii, M36031; Legionella erythra, M36027; Legionella hackeliae, M36028; Legionella longbeachae, M36029; Legionella micdadei, M36032; Legionella pneumophila subsp. pneumophila, M36023; Legionella pneumophila subsp. fraseri, M36025; Legionella spiritensis, M36030; and the isolate LLAP-3, Z49741 $(19,25)$.

\section{RESULTS AND DISCUSSION}

The phenetic relationships among Legionella spp. are summarized in Table 1. As previously noted, the genus Legionella formed a coherent phenotypic taxon (28), and yet comparisons 


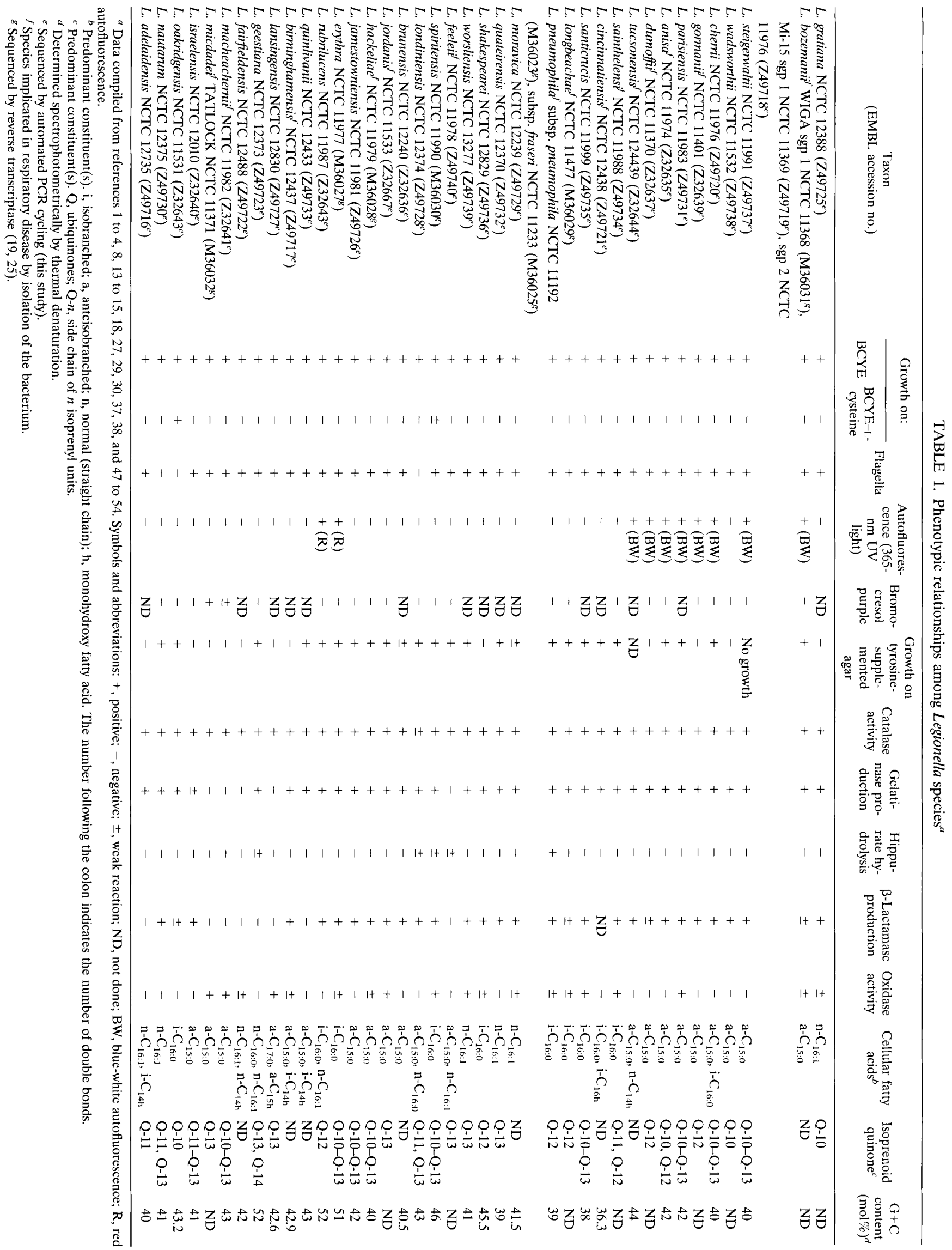




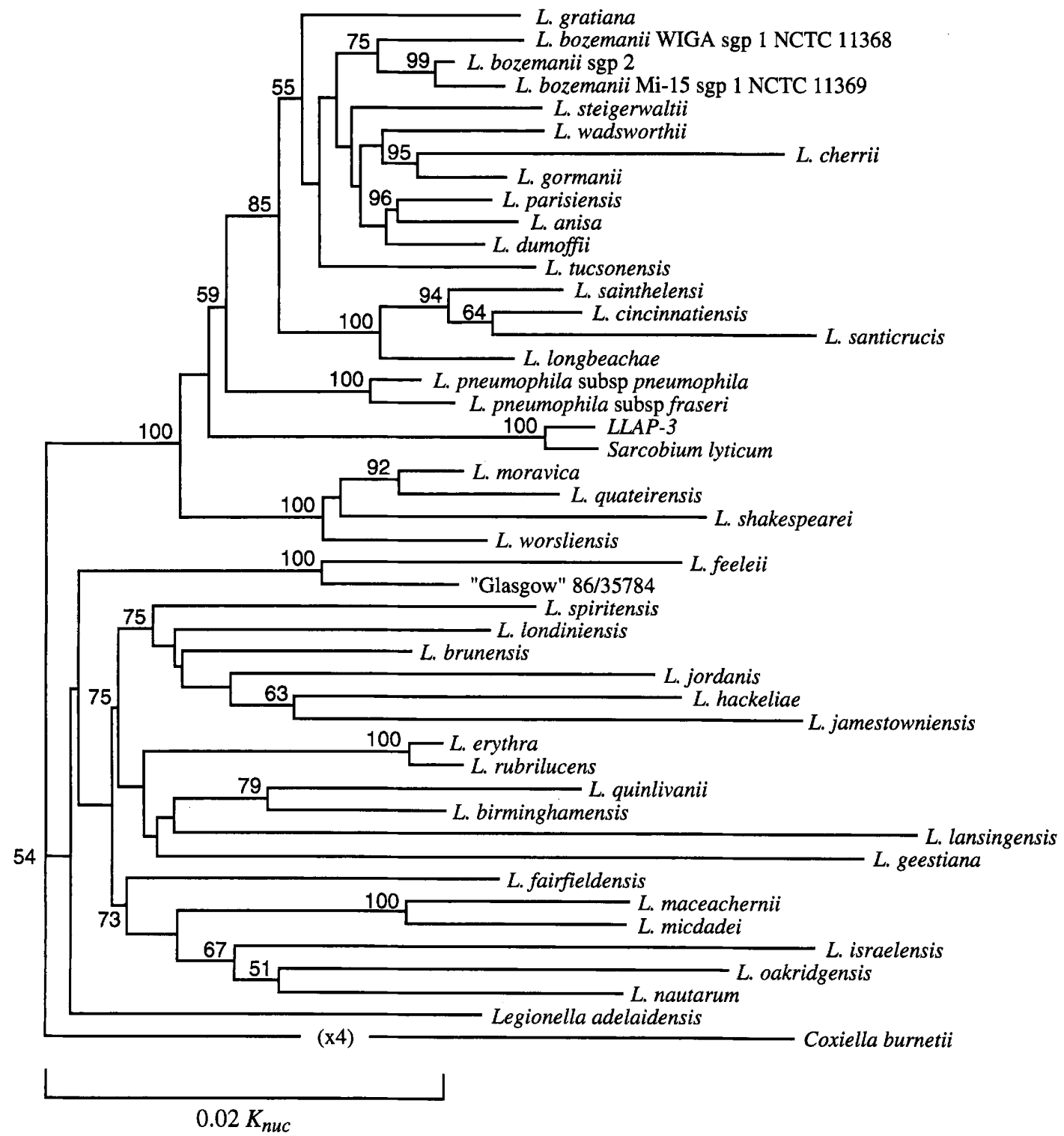

FIG. 1. Unrooted consensus maximum likelihood model and Fitch and Margoliash (21) distance tree showing the position of members of the Legionellaceae, $S$. lyticum, and C. bumetii. Bootstrap percentages quoted are the percentage of times that a taxon occurred at that node. Only values greater than $50 \%$ are shown. The scale bar represented 0.02 substitutions per sequence position $\left(K_{\text {nuc }}\right)$.

of DNA-DNA pairings showed that it was genetically divergent at the species level (5).

All sequences have been submitted to the European Molecular Biology Laboratory, and the accession numbers are given in Table 1. Those for LLAP-3, Sarcobium lyticum, "Glasgow" 86/35785, and Coxiella burnetii (Fig. 1) were Z49741, X66835, Z49724, and M21291, respectively. The results of the current analysis for 45 legionellae are given in Fig. 1. The phylogenetic tree was outgrouped to the etiological agent of $\mathrm{Q}$ fever, $C$. burnetii (Fig. 1) (25).

A comparison of phylogenies based on parsimony, different distance models, and bootstrapped data indicated that the branching order was reliable (Fig. 1). The relative topological positions among $L$. bozemanii, L. erythra, L. hackeliae, $L$. longbeachae, L. pneumophila, L. micdadei, and L. spiritensis were consistent with the picture provided by Fry et al. (25).

The rate of nucleotide substitution $\left(K_{\text {nuc }}\right)$ among those le- gionellae examined varied from $0.0989(90.7 \%)$ for $L$. santicrucis and $L$. jamestowniensis to $0.0053(99.4 \%)$ for the red autofluorescent taxa $L$. erythra and $L$. rubrilucens. Sequence values of between 95 and $97 \%$ are generally expected for different species within a genus (46).

The blue-white autofluorescent species (Table 1) formed a well-defined clade bounded by $L$. bozemanii WIGA and $L$. tucsonensis $\left(K_{\text {nuc }}\right.$ value of $\left.0.0218 ; 97.8 \%\right)$. L. wadsworthii, although nonfluorescent, was part of this clade. It is likely that $L$. wadsworthii represented a line of descent to/from a common blue-white autofluorescent ancestor that had lost the ability to synthesize soluble fluorescent pigments. Few differentiating characters are available for this group, but absence of growth on tyrosine-supplemented agar separated $L$. steigerwaltii from others (Table 1).

The serogroup 1 strain of L. bozemanii Mi-15 (NCTC 11369) had a higher degree of sequence similarity $\left(99.45 \%\right.$ and $K_{\text {nuc }}$ of 
0.0053 ) to the type strain of serogroup 2 (NCTC 11975) than to the serogroup 1 reference strain, WIGA $\left(98.7 \% ; K_{\text {nuc }}, 0.0128\right.$ (Fig. 1). This result may represent some sequence ambiguity inherent within the reverse transcriptase method (25).

Strains of $L$. sainthelensi, L. cincinnatiensis, L. santicrucis, and $L$. longbeachae shared a $16 \mathrm{~S}$ rDNA sequence value of approximately $97.6 \%$, an average $K_{\text {nuc }}$ value of 0.0239 , and a relatively low mol\% $\mathrm{G}+\mathrm{C}$ of about 39.4 (Table 1 ).

The two strains of $L$. pneumophila examined and representing different subspecies were recovered in a separated branch. The two L. pneumophila subspecies pneumophila and fraseri exhibited $99.2 \%$ sequence identity $\left(K_{\text {nuc }}, 0.0079\right)$ and could be identified by their ability to hydrolyze hippurate (Table 1$)$. The designation subspecies rather than genospecies (DNA homology values slightly below the $70 \%$ cutoff criterion for species designation and indistinguishable phenotype) was, in this instance, the exception to the rule (7).

The isolate LLAP-3 was recovered from the sputum of a patient with pneumonia by cocultivation with Acanthamoeba polyphaga (24). On the basis of this study, LLAP-3 showed $99.4 \%$ nucleotide identity $\left(K_{\text {nuc }}, 0.0060\right)$ with another obligate intracellular bacterial parasite, $S$. lyticum (45). There were six nucleotide differences that possibly represented two transitions (both G-A at positions 264 and 473 [Escherichia coli nucleotide numbering [11]) and four transversions (two G-C base-pair substitutions and A-T and C-A at positions 664, 1218, 261, and 1124 , respectively). Both strains resided within the Legionellaceae, and the nearest, yet unrelated, species was L. pneumophila. Since the genus Legionella (originally described in 1979 by Brenner et al. [10]) has precedent over Sarcobium (S. lyticum [17]) according to the Rule of Nomenclatural Priority (44), a proposal is made for the transfer of the species $S$. lyticum from the genus Sarcobium to Legionella as Legionella lytica (17) comb. nov. The description of L. lytica comb. nov. is the same as that published for S. lyticum (17). Cells were gram negative and motile by means of three to five polar flagellar rods that were $0.6 \times 10^{-6}$ to $1.9 \times 10^{-6} \mathrm{~m}$. The DNA base composition as determined by thermal denaturation was 43 mol\% guanine plus cytosine. The organism has chemotype $\mathrm{A}_{1 \mathrm{y}}$ peptidoglycan with a free amino group on the glucosamine residues. It is an obligate intracellular parasite of amoebae that belong to the Acanthamoeba-Naegleria group of protozoa. The type strain was deposited with the Polish Culture Collection as culture PCM 2298. A similar strain (99.4\% 16S rDNA similarity [this study]) would be LLAP-3 (24).

The environmental isolates $L$. moravica, $L$. quateirensis, $L$. shakespearei, and $L$. worsliensis had straight-chain or isobranched cellular fatty acids $\left(\mathrm{n}-\mathrm{C}_{16: 1}, \mathrm{i}-\mathrm{C}_{16: 0}\right)$, an approximate $\mathrm{mol} \% \mathrm{G}+\mathrm{C}$ content of 41.7 (Table 1 ), and an average $K_{\text {nuc }}$ value of $0.0254(97.45 \%)$

The clinical isolate "Glasgow" 86/35784 had unusual colonial yellow autofluorescence under UV light, a nucleotide substitution rate with a $K_{\text {nuc }}$ of 0.0294 , and low similarity $(94.1 \%)$ to its nearest relative, $L$. feeleii. At this level of dissimilarity, it is likely that this strain does represent a new and novel species within the family Legionellaceae.

The legionellae $L$. spiritensis, L. londiniensis, L. brunensis, $L$. jordanis, L. hackeliae, and L. jamestowniensis formed a relatively large segment of the inferred phylogenetic tree. The moles percent $\mathrm{G}+\mathrm{C}$ varied from 40 for $L$. hackeliae to 46 for $L$. spiritensis, distance values were from 0.0642 in $K_{\text {nuc }}(93.8 \%$; $L$. spiritensis- $L$. jamestowniensis) to 0.0326 in $K_{\text {nuc }}(96.8 \% ; L$. londiniensis-L. brunensis), and they had a similarity value of about $95.2 \%$. The phenotypes of these species were not dissimilar, and yet $L$. spiritensis and $L$. londiniensis exhibited vari- able growth on BCYE without L-cysteine supplement and variation in their ability to hydrolyze hippurate (Table 1).

The red autofluorescent taxa $L$. erythra and $L$. rubrilucens were described in 1985 (9) on the basis of DNA pairing studies. Given that strains cross-reacted serologically (43) and have similar biochemical and chemotaxonomic states (Table 1), identical intergenic $16 \mathrm{~S}-23 \mathrm{~S}$ rDNA length polymorphisms (31), comparable sequence comparisons $(99.4 \%$ 16S rDNA [this study]), and DNA hybridization values just below (43) the $70 \%$ cutoff level for species designation, these taxa could be considered subspecies of the same species.

$L$. quinlivanii, L. birminghamensis, $L$. lansingensis, and $L$. geestiana represented a divergent assembly sharing an approximate $K_{\text {nuc }}$ value of 0.0621 and exhibiting sequence variation from $97.1 \%$ (L. quinlivanii-L. birminghamensis) to $91.7 \%(L$. lansingensis-L. geestiana) and $\mathrm{mol} \% \mathrm{G}+\mathrm{C}$ from 52.0 (L. geestiana) to 42.6 (L. lansingensis).

L. fairfieldensis was loosely related at 0.0509 in $K_{\text {nuc }}$ (96.45\%) to L. maceachernii and L. micdadei. The organism was nonautofluorescent, did not degrade gelatin, exhibited variable oxidase activity, and had a mol\% $\mathrm{G}+\mathrm{C}$ of 42 (Table 1; Fig. 1).

Similarities existed between $L$. maceachernii and $L$. micda$d e i$, and yet they differed from other legionellae in giving a positive bromocresol purple spot reaction (26). Garrity and others $(12,26)$ interpreted low DNA homologies between some strains of legionellae to subdivide the family into three genera, namely, Legionella sensu stricto, Tatlockia (maceachernii and micdadei [23]), and Fluoribacter (bozemanii, gormanii, and dumoffii [12]). However, high levels of $16 \mathrm{~S}$ rDNA sequence divergence for some species within a genus are not unknown (22) and should not be used as an argument for splitting a coherent phenotypic family into multiple genera. The results of the current study showed that there are no discrete clusters, as would be expected for a polyphyletic classification. We conclude that all Legionella spp. should be regarded as members of a coherent monophyletic family which belong to the gamma subdivision of the Proteobacteria (25).

On the periphery of the tree were the legionellae $L$. israelensis, L. oakridgensis, L. nautarum, and $L$. adelaidensis. They shared $K_{\text {nuc }}$ values from 0.0714 to 0.0464 (93.1 to $95.5 \%$ ). The absence of polar or lateral flagella and growth on BCYE without an L-cysteine supplement after primary isolation, in part, characterized $L$. oakridgensis.

The phylogenetic structure of the Legionellaceae based on $16 \mathrm{~S}$ rDNA sequence comparisons shows concord with the existing phenetic classification and also supports the call for establishing a polyphasic approach to taxonomy (39).

\section{ACKNOWLEDGMENTS}

We are grateful to S. J. Copping for cultures, C. Arnold and K. L. Barlow for assistance with the DNA sequencing, and J. B. White for artwork.

\section{REFERENCES}

1. Benson, R. F., W. L. Thacker, J. A. Lanser, N. Sangster, W. R. Mayberry, and D. J. Brenner. 1991. Legionella adelaidensis, a new species isolated from cooling tower water. J. Clin. Microbiol. 29:1004-1006.

2. Benson, R. F., W. L. Thacker, R. P. Waters, P. A. Quinlivan, W. R. Mayberry, D. J. Brenner, and H. W. Wilkinson. 1989. Legionella quinlivanii sp. nov. isolated from water. Curr. Microbiol. 18:195-197.

3. Bercovier, H., A. G. Steigerwalt, M. Derhi-Cochin, C. W. Moss, W. Wilkinson, R. F. Benson, and D. J. Brenner. 1986. Isolation of legionellae from oxidation ponds and fishponds in Israel and description of Legionella is- 
raelensis sp. nov. Int. J. Syst. Bacteriol. 36:368-371.

4. Bornstein, N., D. Marmet, M. Surgot, M. Nowicki, H. Meugnier, J. Fleurette, E. Ageron, F. Grimont, P. A. D. Grimont, W. L. Thacker, R. F. Benson, and D. J. Brenner. 1989. Legionella gratiana sp. nov. isolated from French spa water. Res. Microbiol. 140:541-552.

5. Brenner, D. J. 1986. Classification of Legionellaceae: current status and remaining questions. Isr. J. Med. Sci. 22:620-632.

6. Brenner, D. J., J. C. Feeley, and R. E. Weaver. 1984. Family VII Legionellaceae, p. 279-288. In N. R. Krieg and J. G. Holt (ed.), Bergey's manual of systematic bacteriology, vol. 1. Williams \& Wilkins, Baltimore.

7. Brenner, D. J., A. G. Steigerwalt, P. Epple, W. F. Bibb, R. M. McKinney, R. W. Starnes, J. M. Colville, R. K. Selander, P. H. Edelstein, and C. W. Moss. 1988. Legionella pneumophila serogroup Lansing 3 isolated from a patient with fatal pneumonia, and descriptions of $L$. pneumophila subsp. pneumophila subsp. nov., L. pneumophila subsp. fraseri subsp. nov., and L. pneumophila subsp. pascullei subsp. nov. J. Clin. Microbiol. 26:16951703.

8. Brenner, D. J., A. G. Steigerwalt, G. W. Gorman, R. E. Weaver, J. C. Feeley, L. G. Cordes, H. W. Wilkinson, C. Patton, B. M. Thomason, and K. R. Lewallen Sasseville. 1980. Legionella bozemanii sp. nov. and Legionella dumoffii sp. nov.: classification of two additional species of Legionella associated with human pneumonia. Curr. Microbiol. 4:111-116.

9. Brenner, D. J., A. G. Steigerwalt, G. W. Gorman, H. W. Wilkinson, W. F. Bibb, M. Hackel, R. L. Tyndall, J. Campbell, J. C. Feeley, W. L. Thacker, P. Skaliy, W. T. Martin, B. J. Brake, B. S. Fields, H. V. McEachern, and L. K. Corcoran. 1985. Ten new species of Legionella. Int. J. Syst. Bacteriol. 35: 50-59.

10. Brenner, D. J., A. G. Steigerwalt, and J. E. McDade. 1979. Classification of the Legionnaires' disease bacterium: Legionella pneumophila, genus novum, species nova, of the family Legionellaceae. Ann. Intern. Med. 90:656-658.

11. Brosius, J., M. L. Palmer, P. J. Kennedy, and H. F. Noller. 1978. Complete nucleotide sequence of a $16 \mathrm{~S}$ ribosomal RNA gene from Escherichia coli. Proc. Natl. Acad. Sci. USA 75:4801-4805.

12. Brown, A., G. M. Garrity, and R. Vickers. 1981. Fluoribacter dumoffi (Bren ner et al.) comb. nov. and Fluoribacter gormanii (Morris et al.) comb. nov. Int. J. Syst. Bacteriol. 31:111-115.

13. Campbell, J., W. F. Bibb, M. A. Lambert, S. Eng, A. G. Steigerwalt, J. Allard, C. W. Moss, and D. J. Brenner. 1984. Legionella sainthelensi: a new specie of Legionella isolated from water near Mt. St. Helens. Appl. Environ. Microbiol. 47:369-373.

14. Cherry, W. B., G. W. Gorman, L. H. Orrison, C. W. Moss, A. G. Steigerwalt H. W. Wilkinson, S. E. Johnson, R. M. McKinney, and D. J. Brenner. 1982 Legionella jordanis: a new species of Legionella isolated from water and sewage. J. Clin. Microbiol. 15:290-297.

15. Corpet, F. 1988 . Multiple sequence alignment with hierarchical clustering Nucleic Acids Res. 16:453-460.

16. Dennis, P. J., D. J. Brenner, W. L. Thacker, R. Wait, G. Vesey, A. G. Steigerwalt, and R. F. Benson. 1993. Five new Legionella species isolated from water. Int. J. Syst. Bacteriol. 43:329-337.

17. Drozanski, W. 1991. Sarcobium lyticum gen. nov., sp. nov., an obligate intracellular bacterial parasite of small free-living amoebae. Int. J. Syst. Bacteriol. 41:82-87.

18. Edelstein, P. H., D. J. Brenner, C. W. Moss, A. G. Steigerwalt, E. M. Francis, and W. L. George. 1982. Legionella wadsworthii species nova: a cause of human pneumonia. Ann. Intern. Med. 97:809-813.

19. Embley, T. M., J. Smida, and E. Stackebrant. 1988. Reverse transcriptase sequencing of $16 \mathrm{~S}$ ribosomal RNA from Faenia rectivirgula, Pseudonocardia thermophila and Saccharopolyspora hirsuta, three wall type IV actinomycetes which lack mycolic acids. J. Gen. Microbiol. 134:961-966.

20. Feeley, J. C., R. J. Gibson, G. W. Gorman, N. C. Langford, J. K. Rasheed, D. C. Mackel, and W. B. Baine. 1979. Charcoal-yeast extract agar: primary isolation medium for Legionella pneumophila. J. Clin. Microbiol. 10:437-441.

21. Fitch, W. M., and E. Margoliash. 1967. Construction of phylogenetic trees A method based on mutation distances as estimated from cytochrome $c$ sequences is of general applicability. Science 155:279-284.

22. Fox, G. E., J. D. Wisotzkey, and P. Jurtshuk, Jr. 1992. How close is close: 16S rRNA sequence identity may not be sufficient to guarantee species identity. Int. J. Syst. Bacteriol. 42:166-170.

23. Fox, K. F., A. Brown, A. Fox, and G. Schnitzer. 1991. Tatlockia, a genetically and chemically distinct group of bacteria. Proposal to transfer Legionella maceachernii (Brenner et al.) to the genus Tatlockia, as Tatlockia maceach ernii comb. nov. Syst. Appl. Microbiol. 14:52-56.

24. Fry, N. K., T. J. Rowbotham, N. A. Saunders, and T. M. Embley. 1991. Direct amplification and sequencing of the $16 \mathrm{~S}$ ribosomal DNA of an intracellular Legionella species recovered by amoebal enrichment from the sputum of a patient with pneumonia. FEMS Microbiol. Lett. 83:165-168.

25. Fry, N. K., S. Warwick, N. A. Saunders, and T. M. Embley. 1991. The use of $16 \mathrm{~S}$ ribosomal RNA analyses to investigate the phylogeny of the family Legionellaceae. J. Gen. Microbiol. 137:1215-1222.

26. Garrity, G. M., A. Brown, and R. M. Vickers. 1980. Tatlockia and Fluoribacter: two new genera of organisms resembling Legionella pneumophila. Int J. Syst. Bacteriol. 30:609-614.
27. Gorman, G. W., J. C. Feeley, A. Steigerwalt, P. H. Edelstein, W. C. Moss, and D. J. Brenner. 1985. Legionella anisa: a new species of Legionella isolated from potable waters and a cooling tower. Appl. Environ. Microbiol. 49: 305-309.

28. Harris, T. G., and N. A. Saunders. 1994. Taxonomy and typing of legionellae. Rev. Med. Microbiol. 5:79-90.

29. Hebert, G. A., A. G. Steigerwalt, and D. J. Brenner. 1980. Legionella micdadei species nova: classification of a third species of Legionella associated with human pneumonia. Curr. Microbiol. 3:255-257.

30. Herwaldt, L. A., G. W. Gorman, T. MeGrath, S. Toma, B. Brake, A. W. Hightower, J. Jones, A. L. Reingold, P. A. Boxer, P. W. Tang, C. W. Moss, H. Wilkinson, D. J. Brenner, A. G. Steigerwalt, and C. V. Broom. 1984. A new Legionella species, Legionella feeleii species nova, causes pontiac fever in a automobile plant. Ann. Intern. Med. 100:333-338.

31. Hookey, J. V., R. J. Birtles, and N. A. Saunders. 1995. Intergenic 16S rRNA gene (rDNA)-23S rDNA sequence length polymorphisms in members of the family Legionellaceae. J. Clin. Microbiol. 33:2377-2381.

32. Hookey, J. V., J. Bryden, and L. Gatehouse. 1993. The use of 16S rDNA sequence analysis to investigate the phylogeny of Leptospiraceae and related spirochaetes. J. Gen. Microbiol. 139:2585-2590.

33. Jukes, T. H., and C. R. Cantor. 1969. Evolution of protein molecules, p. 21-132. In H. N. Munro (ed.), Mammalian protein metabolism. Academic Press, New York.

34. Karr, D. E., W. F. Bibb, and C. W. Moss. 1982. Isoprenoid quinones of the genus Legionella. J. Clin. Microbiol. 15:1044-1048.

35. Lane, D. J., K. G. Field, G. J. Olsen, and N. R. Pace. 1988. Reverse transcriptase sequencing of ribosomal RNA for phylogenetic analysis. Methods Enzymol. 167:138-141.

36. Lane, D. J., B. Pace, G. J. Olsen, D. A. Stahl, M. L. Sogin, and N. R. Pace. 1985. Rapid determination of $16 \mathrm{~S}$ ribosomal RNA sequences for phylogenetic analyses. Proc. Natl. Acad. Sci. USA 82:6955-6959.

37. McKinney, R. M., R. K. Porscen, P. H. Edelstein, M. L. Bissett, P. P. Harris, S. P. Bondell, A. G. Steigerwalt, R. E. Weaver, M. E. Ein, D. S. Lindquist, R. S. Kops, and D. J. Brenner. 1981. Legionella longbeachae species nova, another etiological agent of human pneumonia. Ann. Intern. Med. 94:739743

38. Morris, G. K., A. G. Steigerwalt, J. C. Feeley, E. S. Wong, W. T. Martin, C. M. Patton, and D. J. Brenner. 1980. Legionella gormanii sp. nov. J. Clin. Microbiol. 12:718-721.

39. Murray, R. G. E., D. J. Brenner, R. R. Colwell, P. De Vos, M. Goodfellow, P. A. D. Grimont, N. Pfennig, E. Stackebrandt, and G. A. Zavarzin. 1990. Report of the Ad Hoc Committee on Approaches to Taxonomy within the Proteobacteria. Int. J. Syst. Bacteriol. 40:213-215.

40. Orrison, L. H., W. B. Cherry, R. L. Tyndall, C. B. Fliermans, S. B. Gough, M. A. Lambert, L. Kirven McDougal, W. F. Bibb, and D. J. Brenner. 1983. Legionella oakridgensis: unusual new species isolated from cooling tower water. Appl. Environ. Microbiol. 45:536-545.

41. Saitou, N., and M. Nei. 1987. The neighbour joining method: a new method for constructing phylogenetic trees. Mol. Biol. Evol. 4:406-425.

42. Saunders, N. A. 1991. Analysis of restriction fragment length polymorphisms (RFLPs) in the study of bacteria. Soc. Appl. Microbiol. Tech. Ser. 28: 227-244.

43. Saunders, N. A., N. Doshi, and T. G. Harrison. 1992. A second serogroup of Legionella erythra serologically indistinguishable from Legionella rubrilucens. J. Appl. Bacteriol. 72:262-265.

44. Sneath, P. H. A. (ed.). 1992. International code of nomenclature of bacteria (1990 revision), 1992 ed. American Society for Microbiology, Washington, D.C

45. Springer, N., W. Ludwig, W. Drozanski, R. Amann, and K. H. Schleifer. 1991. The phylogenetic status of Sarcobium lyticum, an obligate intracellular parasite of small amoebae. FEMS Microbiol. Lett. 96:199-202.

46. Stackebrandt, E., and B. M. Goebel. 1994. Taxonomic note: a place for DNA-DNA reassociation and 16S rRNA sequence analysis in the present species definition in bacteriology. Int. J. Syst. Bacteriol. 44:846-849.

47. Thacker, W. L., R. F. Benson, L. Hawes, H. Gidding, B. Dwyer, W. R. Mayberry, and D. J. Brenner. 1991. Legionella fairfieldensis sp. nov. isolated from cooling tower waters in Australia. J. Clin. Microbiol. 29:475-478.

48. Thacker, W. L., R. F. Benson, R. B. Schifman, E. Pugh, A. G. Steigerwalt, W. R. Mayberry, D. J. Brenner, and H. W. Wilkinson. 1989. Legionella tucsonensis sp. nov. isolated from a renal transplant recipient. J. Clin. Microbiol. 27:1831-1834.

49. Thacker, W. L., R. F. Benson, J. L. Staneck, S. R. Vincent, S. R. Mayberry, D. J. Brenner, and H. W. Wilkinson. 1988. Legionella cincinnatiensis sp. nov. isolated from a patient with pneumonia. J. Clin. Microbiol. 26: $418-420$

50. Thacker, W. L., J. W. Dyke, R. F. Benson, D. H. Havlichek, Jr., B. RobinsonDunn, H. Stiefel, W. Schneider, C. W. Moss, W. R. Mayberry, and D. J. Brenner. 1992. Legionella lansingensis sp. nov. isolated from a patient with pneumonia and underlying chronic lymphocytic leukemia. J. Clin. Microbiol. 30:2398-2401.

51. Verma, U. K., D. J. Brenner, W. L. Thacker, R. F. Benson, G. Vesey, J. B. Kurtz, P. J. L. Dennis, A. G. Steigerwalt, J. S. Robinson, and C. W. Moss. 
1992. Legionella shakespearei sp. nov., isolated from cooling tower water. Int. J. Syst. Bacteriol. 42:404-407.

52. Waite, R. 1988. Confirmation of identity of legionellae by whole cell fattyacid and isoprenoid quinone profiles, p. 69-101. In T. G. Harrison and A. G. Taylor (ed.), A laboratory manual for Legionella. John Wiley, Chichester, United Kingdom.

53. Wilkinson, H. W., V. Drasar, W. L. Thacker, R. F. Benson, J. Schindler, B. Potuznikova, W. R. Mayberry, and D. J. Brenner. 1988. Legionella moravica sp. nov. isolated from cooling-tower water. Ann. Inst. Pasteur/ Microbiol. (Paris) 139:393-402.

54. Wilkinson, H. W., W. L. Thacker, R. F. Benson, S. S. Polt, E. Brookings, W. R. Mayberry, D. J. Brenner, R. G. Gilley, and J. K. Kirklin. 1987. Legionella birminghamensis sp. nov. isolated from a cardiac transplant recipient. J. Clin. Microbiol. 25:2120-2122.

55. Zhen, L., and R. T. Swank. 1993. A simple and high yield method for recovering DNA from agarose gels. BioTechniques 14:894-898. 